\title{
LONG-TERM EFFECTS OF CARBON FIBRE ON SOFT TISSUES
}

\author{
KEITH TAYTON, GLAN PHILLIPS, ZDENEK RÁLIŠ \\ From the Department of Traumatic and Orthopaedic Surgery, \\ Welsh National School of Medicine, Cardiff
}

\begin{abstract}
To investigate the carcinogenic potential for carbon fibre, strand and powdered forms of it were implanted into the muscle and around the bone in the hind legs of 110 rats. A further 60 rats had silk implanted into the same compartments for control purposes. On histological examination, after an average period of just over 17 months, there were no signs of any malignant change.
\end{abstract}

Parallel with the development of carbon fibre as an implant material (Jenkins et al. 1977; Forster et al. 1978; Jenkins and McKibbin 1980) the present study was set up to investigate any long-term, undesirable side-effects which the continuous presence of this material might produce, especially any evidence of carcinogenic activity. As carbon fibre tends to break up after long-term implantation, and as tissue reactions to the solid and powdered forms of a material may be quite different (Oppenheimer et al. 1958; Wroblewski 1979), the experiments were conducted with the carbon in two distinct physical states. In the first two experiments solid strands of carbon fibres were implanted, but in the third a powder was used.

\section{METHOD AND MATERIAL}

The experiment was carried out on three groups of adult Wistar rats. Group I. Under general ether anaesthesia 1.5 centimetres of AS3000 non-braided carbon-fibre filament (Grafil) was inserted intramuscularly into the left gluteal muscle of 50 rats. The skin wounds were sutured with Dexon. This procedure was repeated on a further 50 rats (as controls) using six 1.5 centimetre strands of 2-0 black braided silk suture material as the implant.

Group II. A five-centimetre length of AS3000 non-braided carbonfibre filament was tied around the mid-shaft over the periosteum of the left femur of 10 rats. Ten more rats were used as controls and in these a five-centimetre length of six strands of 2-0 black braided silk was tied around the femur. All wounds were closed with Dexon.

Group III. Fifteen centimetres of AS3000 non-braided carbon-fibre filament were broken up with a pestle and mortar into a powder to which was added 25 millilitres of normal saline; 2.5 millilitres of the suspension thus formed were injected into the left gluteal muscle of each of 10 rats. This process was repeated until each of 50 rats had been injected with the equivalent, in powder, of 1.5 centimetres of the carbon fibre being investigated.

All surviving rats were killed by cervical dislocation at 18 months. After removal of the skin, the muscle mass of the left gluteal region and the left thigh, including the femur. was dissected out and fixed in neutral buffered 10 per cent formol for two to four weeks. Later dissection, in serial vertical layers. identified the sites of implantation from which blocks for histology were taken. These were embedded in paraffin, and the sections were stained by haematoxylin and eosin, and by the Goldner's trichrome.

\section{RESULTS}

From their investigations, Oppenheimer et al. (1955, 1958) concluded that tumours appear in rats between one and two years after a carcinogenic implant has been embedded, and they suggested that a minimal latent period of 300 days must elapse before the risks of carcinogenesis are significant. In the present study some animals died before completion of the experiment, but all of them were examined for local tissue reactions; if benign, the results were ignored unless the minimal carcinogenic latent period had passed. In no case was death connected with the presence of the implant.

Group I. The animals in this group were killed at an average of 17.2 months after the insertion of the implant, 94 of them living well beyond the minimal latent period of 300 days. The tissue reaction around and within the carbon fibre implant was generally very small (Fig. 1). As expected there were no signs of any inflammatory reaction: the whole implant was surrounded by a thin capsule of quiescent fibrous tissue, and the individual carbon filaments were coated with variable numbers of epithelioid cells, the numbers of which were greater when the fibres were less tightly packed. A considerable quantity of carbon debris was noted in the interstitium and some of this was also seen in phagocytic cells and the nearby lymphatic capillaries. In most of the animals the reaction corresponded to the first stage of the tissue reaction to carbon fibre (Forster et al. 1978) but, in a few; the tissue response had reached the more advanced stage in which the coated carbon fibres were more widely separated by young granulation tissue, which was also adding to the thickness of the capsule. Only occasional giant cells were seen. The muscle tissue itself exhibited little reaction apart from
K. J. J. Tayton, FRCS, Senior Lecturer G. E. Phillips, FRCS, Senior Registrar Z. A. Ráliš̌, FCCS, Senior Lecturer

Requests for reprints should be sent to Mr K. J. J. Tayton.

Department of Traumatic and Orthopaedic Surgery,

Cardiff Royal Infirmary, Cardiff CF2 isZ, Wales.

(1) 1982 British Editorial Society of Bone and Joint Surgery 0301-620X/82/1005-0112\$2.00 


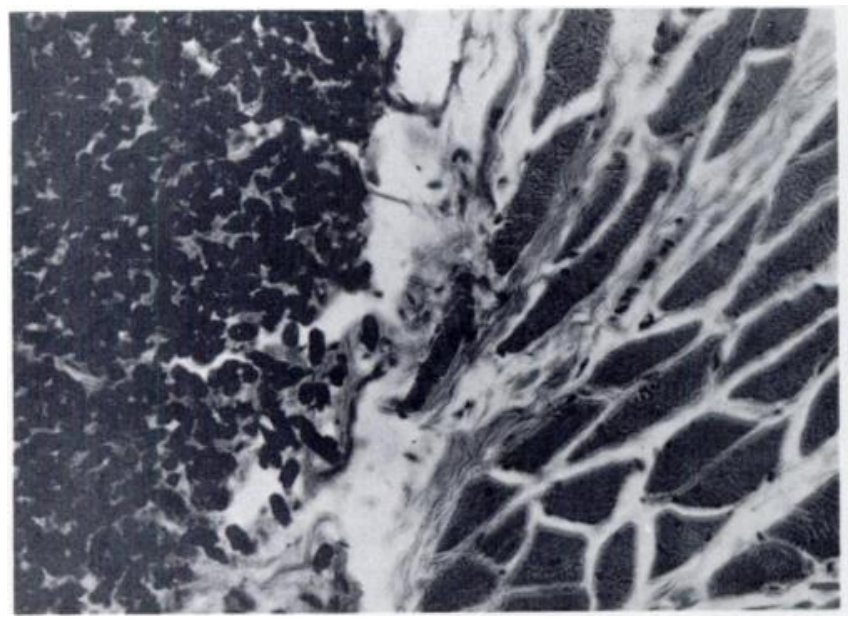

Fig. 1

A transverse section of carbon fibre in the vicinity of muscle fibres, 18 months after implantation. Note the minimal cellular reaction in and around the implant. (Haematoxylin and eosin, $\times 100$ ).

the occasional presence of myotubes, dysplastic muscle fibres and thickening of the endomysium.

In contrast, the silk implants were surrounded by a thick, highly cellular capsule containing chronic granulation tissue with many plasma cells, monocytes and lymphocytes (Fig. 2). The silk fibres themselves were thickly coated with epithelioid cells and many foreignbody giant cells were noted. No silk particles were seen in the tissues and the lymphatics were also clear.

In no animal in this group was there any sign of a malignant process.

Group II. The animals in this group were killed at an average of 14.3 months after the carbon fibre was tied around their femora. Eighteen lived beyond the minimal carcinogenic latent period. The histological findings were parallel to those seen in Group I. In this group, the material forming the thick fibrous capsule and some coating cells seemed to originate from the outer layer of the periosteum and nearby perimysial spaces. No

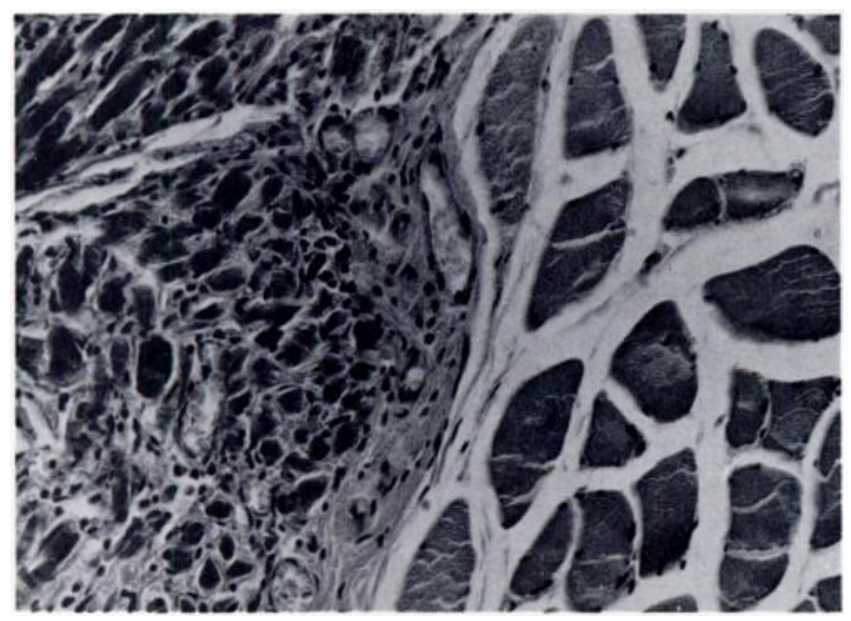

Fig. 2

A transverse section of silk suture material in the vicinity of muscle fibres, 18 months after implantation. Note the abundant cellular reaction and the capillaries of chronic granulation tissues surrounding the individual silk filaments. (Haematoxylin and eosin, $\times 100$ ). unusual bone reactions to the implants were noted and no malignant changes were seen.

Group III. These rats were killed at an average of 18.4 months after the intramuscular injection of the suspension of carbon powder. Forty animals lived well beyond the minimal carcinogenic latent period, but in only 30 of these was it possible to find the injected material under the microscope. As can be seen in Figure 3, most of the injected carbon fragments were located in the interstitial spaces of the muscle. The carbon particles excited only a minimal reaction in which sparse "coating cells", minor fibrosis and occasional foreign-body giant cells were seen. Some of the smaller carbon fragments were present in lymphatic capillaries. Apart from occasional areas of thickened endomysium, the muscle tissue itself showed no reaction at all. In no animal was there any sign of malignant change.

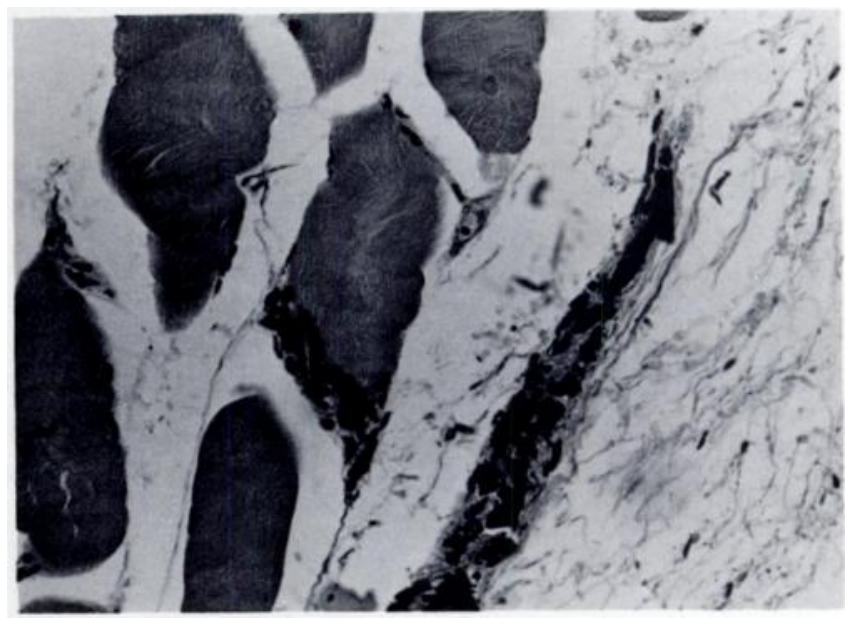

Fig. 3

Particles of "powdered" carbon fibre external to and between muscle fibres, 18.4 months after implantation. Note the minimal reaction of the host tissues. (Haematoxylin and eosin, $\times 200$ )

\section{DISCUSSION}

Reports on the tissue response to implanted carbon fibre have been limited, with only very few animals being studied histologically after three months (Jenkins et al. 1977; Forster et al. 1978). In this long-term study no case of malignant change has been found, and the tissue reactions were considerably more muted to the carbonfibre implants than to the silk used for controls. The general response to the implant, even in a finely divided form, is reassuring with regard to both muscle and tissues in the vicinity of bone.

In investigating carcinogenicity, it is recognised that the 18 months' duration of these experiments is very short in comparison with the time of action of most known human carcinogens. Nevertheless, this period represents much of the lifespan of a laboratory Wistar rat, which rarely survives longer than two years under normal conditions (UFAW 1976) and it is this ratio which may be the more relevant consideration; also, the rat is known to be particularly prone to develop malignant tumours in response to carcinogens even after 
a comparatively brief period of exposure. Thus tumours have been reported in their subcutaneous tissues in response to Silastic, to polymethylmethacrylate and to polyethylene of high molecular weight (Oppenheimer $e t$ al. 1955) and in their muscle in response to chromecobalt alloy (Heath, Freeman and Swanson 1971) all after only a few months' exposure. All of these materials have been in use in the human for many years without any evidence of carcinogenicity. Hence the results in the present study, so far as they go, give no cause for concern in this respect, and for the present there seems to be no contra-indication to the clinical use of carbon fibre.

\section{REFERENCES}

Forster IW, Rálǐ̌ ZA, McKibbin B, Jenkins DHR. Biological reaction to carbon fiber implants. Clin Orthop 1978;131:299-307.

Heath JC, Freeman MAR, Swanson SAV. Carcinogenic properties of wear particles from prostheses made in cobalt-chromium alloy. Lancet $1971:$ i:564-6.

Jenkins DHR, Forster IW, McKibbin B, Ráliš ZA. Induction of tendon and ligament formation by carbon implants. J Bone Joint Surg [Br] 1977;59-B:53-7.

Jenkins DHR, McKibbin B. The role of flexible carbon-fibre implants as tendon and ligament substitutes in clinical practice.J Bone Joint Surg [Br] 1980;62-B:497-9.

Oppenheimer BS, Oppenheimer ET, Danishefsky I, Stout AP, Eirich FR. Further studies of polymers as carcinogenic agents in animals. Cancer Res 1955;15:333-40.

Oppenheimer BS, Oppenheimer ET, Stout AP, Willhite M, Danishefsky I. The latent period in carcinogenesis by plastics in rats and its relation to the presarcomatous stage. Carrer 1958;11:204-13.

Universities Federation for Animal Welfare. The UFAW handbook on the care and management of laboratory animals. 5th ed. Edinburgh, London: Churchill Livingstone, 1976.

Wroblewski BM. Wear of high-density polyethylene in bone and cartilage. J Bone Joint Surg [Br] 1979;61-B:498-500. 